\title{
Inhibition of PPAR $\gamma$, adipogenesis and insulin sensitivity by MAGED1
}

\author{
Qinghua Wang1,2,*, Jing Tang1,*, Shujun Jiang1,3, Zan Huang1,4, Anying Song1, Siyuan Hou', Xiang Gao1 and \\ Hai-Bin Ruan 5
}

1State Key Laboratory of Pharmaceutical Biotechnology and MOE Key Laboratory of Model Animal for Disease Study, Model Animal Research Center, Nanjing Biomedical Research Institute, Nanjing University, Nanjing, Jiangsu, China

2Laboratory Animal Center, Nantong University, Nantong, Jiangsu, China

${ }^{3} 5$ chool of Traditional Chinese Medicine, China Pharmaceutical University, Nanjing, Jiangsu, China

4Laboratory of Gastrointestinal Microbiology, Jiangsu Key Laboratory of Gastrointestinal Nutrition and Animal Health, College of Animal Science and Technology, Nanjing Agricultural University, Nanjing, Jiangsu, China

${ }^{5}$ Department of Integrative Biology and Physiology, University of Minnesota Medical School, Minneapolis, Minnesota, USA

Correspondence should be addressed to X Gao or H-B Ruan: gaoxiang@nju.edu.cn or hruan@umn.edu

*(Q Wang and J Tang contributed equally to this work)

\section{Abstract}

Peroxisome proliferator-activated receptor- $\gamma$ (PPAR $\gamma$ ) is a master regulator of adipogenesis and a target of the thiazolidinedione (TZD) class of antidiabetic drugs; therefore, identifying novel regulators of PPAR $\gamma$ action in adipocytes is essential for the future development of therapeutics for diabetes. MAGE family member D1 (MAGED1), by acting as an adaptor for ubiquitin-dependent degradation pathways and a co-factor for transcription, plays an important role in neural development, cell differentiation and circadian rhythm. Here, we showed that MAGED1 expression was downregulated during adipogenesis and loss of MAGED1 promoted preadipocyte proliferation and differentiation in vitro. MAGED1 bound to PPAR $\gamma$ and suppressed the stability and transcriptional activity of PPAR $\gamma$. Compared to WT littermates, MAGED1-deficient mice showed increased levels of PPAR $\gamma$ protein and its target genes, more CD29+CD34+Sca-1+ adipocyte precursors and hyperplasia of white adipose tissues (WATs). Moreover, MAGED1-deficient mice developed late-onset obesity as a result of decreased energy expenditure and physical activity. However, these mice were metabolically healthy as shown by improved glucose clearance and insulin sensitivity, normal levels of serum lipids and enhanced secretion of adipokines such as leptin and adiponectin. Taken together, our data identify MAGED1 as a novel negative regulator of PPAR $\gamma$ activity, adipogenesis and insulin sensitivity in mice. MAGED1 might therefore serve as a novel pharmaceutical target to treat obesity-associated insulin resistance.

\section{Key Words}

- obesity

- insulin sensitivity

- PPAR $\gamma$ stability

- energy expenditure

- MAGE gene family

\section{Introduction}

The obesity epidemic continues to rise as a global health challenge. Obesity is a major risk factor for high blood pressure, hyperlipidemia, diabetes, heart disease, cancers, etc. (Ng et al. 2014, Ogden et al. 2014). The white adipose tissue (WAT) serves as a critical integrator of energy balance and glucose homeostasis by storing excess energy to prevent ectopic fat accumulation in non-adipose tissues and by secreting various adipokines to modulate whole-body metabolism (Ouchi et al. 2011). Adipocyte hyperplasia, or adipogenesis, is the process of adipocyte 
differentiation from pre-adipocytes, which reside in the stromal vascular fraction (SVF) of WAT (Rosen \& MacDougald 2006, Gesta et al. 2007, Tran \& Kahn 2010). The nuclear receptor peroxisome proliferator-activated receptor- $\gamma(\operatorname{PPAR} \gamma)$ is a master regulator of adipogenesis and most pro- and anti-adipogenic factors seem to function at least in part by regulating PPAR $\gamma$ expression and/or activity (Farmer 2006, Rosen \& MacDougald 2006). The thiazolidinedione (TZD) class of antidiabetic drugs agonize PPAR $\gamma$ to activate adipogenesis and sensitize insulin action (Spiegelman 1998). The PPAR $\gamma$ protein is short-lived as it can be ubiquitinated and degraded through the proteasome (Floyd \& Stephens 2002, van Beekum et al. 2009, Kim et al. 2014). Activation by TZDs further accelerates PPAR $\gamma$ degradation; therefore, understanding how PPAR $\gamma$ stability is controlled will shed light on new strategies to fine-tune this metabolic master regulator to treat type 2 diabetes.

Melanoma antigen (MAGE) family member D1 (MAGED1), also known as neurotrophin receptorinteracting MAGE (NRAGE) and DLXIN-1, plays an important role in transcription, cell signaling and protein stability (Di Certo et al. 2007, Doyle et al. 2010, Wang et al. 2010, Mouri et al. 2012). Growing evidence demonstrates that MAGED1 interacts with proteins such as DLX5 (Masuda et al. 2001), p75NTR (Salehi et al. 2000), ITA and XIAP (Jordan et al. 2001), UNC5H1 (Williams et al. 2003), ROR2 (Matsuda et al. 2003) and ROR $\alpha$ (Wang et al. 2010) to regulate neural development, cell apoptosis and proliferation and circadian rhythm. We and others have showed that MAGED1-knockout mice exhibit a shortened circadian period and bouts (Wang et al. 2010), impaired learning and memory (Yang et al. 2015) and an osteoporotic phenotype (Liu et al. 2015). However, the role of MAGED1 in energy and glucose metabolism has not been studied.

Recently, MAGE family proteins were shown to bind really interesting new gene (RING) domain proteins to form active E3 ubiquitin ligases (Doyle et al. 2010). For example, the MAGEC2-TRIM28 complex targets p53 for proteasomal degradation (Doyle et al. 2010). The MAGEL2-TRIM27 promotes K63-linked ubiquitination of WASH, thus facilitating endosomal F-actin nucleation and retromer-mediated transport (Hao et al. 2013). Likewise, MAGED1 interacts with RING proteins including PRAJA-1 (Sasaki et al. 2002), and TRIM28 to a less extent (Doyle et al. 2010). In addition, MAGED1 controls the degradation of the anti-apoptotic factor CHE-1 (Di Certo et al. 2007), and the activity and ubiquitylation of the serotonin transporter (Mouri et al. 2012). In this study, we report that MAGED1 interacts with PPAR $\gamma$ and decreases its stability. Loss of
MAGED1 leads to enhanced preadipocyte proliferation and adipogenesis. MAGED1-deficient mice develop obesity but lack metabolic abnormalities including dyslipidemia, impaired glucose tolerance and insulin resistance.

\section{Materials and methods}

\section{Animals}

C57BL/6J mice from Jackson Laboratory and Maged1knockout (KO) mice (Wang et al. 2010) were maintained in an AAALAC-accredited, specific pathogen-free facility in Model Animal Research Center of Nanjing University. All animal protocols were approved by Institutional Animal Care and Use Committee of Nanjing University, in accordance with published guidelines in the Principles of Laboratory Animal and the Care and Use of Laboratory Animals (National Research Council 1996). All mice were maintained under 12-h light/darkness cycles (light on at 08:00 h and off at 20:00 h) and fed with acidified water and standard chow ad libitum. Maged1-KO mice had been backcrossed to C57BL/6J mice for at least 15 generations.

\section{Serum biochemistry parameters measurements}

Mice were fasted for overnight or $6 \mathrm{~h}$ or refed for $2 \mathrm{~h}$ as indicated. Whole blood was collected from the eye socket vein. Serum was collected after a centrifugation at $3000 \mathrm{~g}$ for $15 \mathrm{~min}$. Lipid metabolites in plasma including total cholesterol, triglyceride (TG), high-density lipoprotein and low-density lipoprotein (VLDL) were quantified by colorimetric assays with a 7020 automatic analyzer (Hatachi High Technology, Japan).

\section{Glucose and insulin tolerance tests}

For oral glucose tolerance test, mice were fasted from 17:00 to 09:00 h and injected with $\mathrm{D}(+)$-glucose (Sigma, $2 \mathrm{~g} / \mathrm{kg}$ body weight). For insulin tolerance test (ITT), mice were fasted from 09:00 to 15:00 h and injected with $0.75 \mathrm{U}$ insulin (Novo Nordisk) per $1 \mathrm{~kg}$ body weight. Blood glucose concentrations were determined by GLUCOCARD II Test Meters (Arkray, Minneapolis, MN, USA).

\section{Metabolic characterization and body composition analyses}

The Comprehensive Lab Animal Monitoring System was used to determine food intake, physical activity, oxygen 
consumption and carbon dioxide production. All mice were maintained in a $12: 12$ light/darkness cycle at $22^{\circ} \mathrm{C}$ and acclimated for 2 days. Data were recorded for at least $72 \mathrm{~h}$ for analyses.

A dual-energy X-ray absorptiometry system (GE Medical System Lunar, Madison, WI, USA) was used to determine body composition. Mice were anesthetized with Avertin (Sigma Aldrich) and kept on a heat plate for data acquisition.

\section{Histology}

Tissues were collected and fixed in $4 \%$ formalin (in PBS) overnight, embedded in paraffin and sectioned at a thickness of $5 \mu \mathrm{m}$. Slides were dewaxed with xylene, rehydrated with descending grades of ethanol and then rinsed with distilled water. Tissue sections were then stained with hematoxylin and eosin. ImageJ was used for quantification of adipocyte size and area from histological slides. In brief, images were transformed into 8-bit and the image threshold was set to selectively visualize adipocyte prior analyses. All the images were acquired with the Coolscope Microscope (Nikon).

For immunohistochemistry, tissue sections were deparaffinized, antigen was retrieved by steaming for $30 \mathrm{~min}$ and then cooled to room temperature. Slides were blocked with $5 \%$ BSA for $1 \mathrm{~h}$, incubated with anti-BrdU primary antibody (rat monoclonal, Abcam) overnight at $4^{\circ} \mathrm{C}$ and secondary antibody conjugated with cyanine 5 (eBioscience). Images were observed with a confocal laserscanning microscope (FV1000, Olympus MicroImaging).

\section{Isolation and differentiation of adipose SVF cells}

Adipose tissues were excised, washed with PBS and minced in digestion buffer (100 mM HEPES pH 7.4, $120 \mathrm{mM} \mathrm{NaCl}$, $50 \mathrm{mM} \mathrm{KCl}, 5 \mathrm{mM}$ glucose, $1 \mathrm{mM} \mathrm{CaCl}_{2}, 1.5 \% \mathrm{BSA}$, and $1 \mathrm{mg} / \mathrm{mL}$ collagenase D (Roche)). Then, the mixture was digested at $37^{\circ} \mathrm{C}$ for $30 \mathrm{~min}$ with shaking at $85 \mathrm{rpm}$. The slurry was filtered through $40 \mu \mathrm{m}$ cell strainer to remove undigested bulks and large adipocytes. After that the aqueous phase was centrifuged for $5 \mathrm{~min}$ at $500 \mathrm{~g}$, the pellet was resuspended in preadipocytes culture medium (DMEM/F12 with Glutamine, $10 \mathrm{mM}$ HEPES, and $25 \mu \mathrm{g} / \mathrm{mL}$ sodium ascorbate). Preadipocytes were seeded on $6 \mathrm{~cm}$ dishes, and medium was changed next morning. Cells were passaged at confluence and frozen for further use.

For adipocyte differentiation, preadipocytes were cultured on poly-lysine-coated dishes to confluence in preadipocyte medium. Cells were kept at confluence for another $24 \mathrm{~h}$ to arrest the cell cycle into the G1 phase. Cells were then induced by basic differentiation medium containing the adipogenic cocktail (850 nM Insulin, $0.5 \mu \mathrm{M}$ dexamethasone, $250 \mu \mathrm{M}$ isobutylmethylxanthine (IBMX) and $1 \mu \mathrm{M}$ rosiglitazone) for $48 \mathrm{~h}$. Cells were then kept in basic preadipocyte culture medium with $850 \mathrm{nM}$ insulin till analyses.

To make Oil-Red O stock, $500 \mathrm{mg}$ of Oil-Red O was dissolved in $100 \mathrm{~mL}$ of isopropanol and kept stirring overnight, avoiding of light. The solution was filtered and stored in dark cabinet for further use. Adipocytes were fixed with $4 \%$ formalin for $1 \mathrm{~h}$, washed with $1 \times$ PBS three times and stained with the Oil-Red $\mathrm{O}$ solution for $1 \mathrm{~h}$. Cells washed with deionized water for four times were imaged. Finally, $1 \mathrm{~mL}$ isopropanol was added to dried wells to dissolve Oil-Red $\mathrm{O}$ for the colorimetric detection.

\section{Flow cytometry}

WATs were excised, washed in PBS solution twice and then minced in the digestion buffer $(100 \mathrm{mM}$ HEPES $\mathrm{pH} 7.4,120 \mathrm{mM} \mathrm{NaCl}, 50 \mathrm{mM} \mathrm{KCl}, 5 \mathrm{mM}$ glucose, $1 \mathrm{mM}$ $\mathrm{CaCl}_{2}, 1.5 \% \mathrm{BSA}$, and $1 \mathrm{mg} / \mathrm{mL}$ collagenase D (Roche)). Tissues were transferred to $15 \mathrm{~mL}$ tubes and incubated at $37^{\circ} \mathrm{C}$ with vibrations at $87 \mathrm{rpm}$. Cell pellets were obtained by centrifugation at $500 \mathrm{~g}$ for $5 \mathrm{~min}$ and resuspended in $1 \mathrm{~mL}$ PBS. After filtering through $100 \mu \mathrm{M}$ strainers, cells were fixed in 70\% ethanol for $20 \mathrm{~min}$ and incubated with $0.1 \%$ TritonX-100 in 5\% BSA solution for $1 \mathrm{~h}$. Cells were stained with antibodies against Sca-1-PE, CD29-PE-Cy5 and CD34-APC (BD Biosciences) on ice for $1 \mathrm{~h}$. Samples were analyzed with a FACSCalibur flow cytometer and the CellQuest software (BD Biosciences).

For MTT assay, passage two preadipocytes were seeded at a density of $8 \times 10^{3}$ per well in 96-well plates. A total of $20 \mu \mathrm{L}$ of $5 \mathrm{mg} / \mathrm{mL}$ MTT were added to each well after $48 \mathrm{~h}$ of culture. Cells were incubated at $37^{\circ} \mathrm{C}$ for $4 \mathrm{~h}$. Culture medium was removed carefully, $150 \mu \mathrm{L}$ MTT solvent was added and plates were shaked at $60 \mathrm{rpm}$ for $15 \mathrm{~min}$ avoiding of light. The absorbance was read at $590 \mathrm{~nm}$ with a reference filter of $620 \mathrm{~nm}$.

\section{Mouse embryonic fibroblasts preparation and culture}

Embryos at day 12.5 were dissected, washed in PBS and transferred into drops of digestion solution ( $0.25 \%$ trypsin, $0.04 \%$ EDTA). Tissues were minced and incubated in $3 \mathrm{~mL}$ of digestion solution at $37^{\circ} \mathrm{C}$ for $15 \mathrm{~min}$. Three milliliters of DMEM plus 10\% FBS were added and then incubated at $37^{\circ} \mathrm{C}$ with occasional shaking for another $15 \mathrm{~min}$. Cells were pelleted by centrifugation at $300 \mathrm{~g}$ for $5 \mathrm{~min}$ and resuspended in DMEM containing 10\% FBS for the culture. 
SV40T antigen integrated lentivirus was used to infect the P2 mouse embryonic fibroblasts (MEFs). Puromycin-selected cells were considered as immortalized MEFs.

\section{Cell culture, transient transfection} and luciferase assay

HEK293, NIH/3T3 and 3T3-L1 cells were cultured in DMEM medium supplemented with $10 \%$ FBS at $37^{\circ} \mathrm{C}, 5 \%$ $\mathrm{CO}_{2}$. 3T3-L1 cells were differentiated similarly as primary SVFs. Briefly, overconfluent 3T3-L1 cells were induced with $1 \mu \mathrm{g} / \mathrm{mL}$ Insulin, $1 \mu \mathrm{M}$ dexamethasone, $0.5 \mathrm{mM}$ IBMX and $1 \mu \mathrm{M}$ troglitazone for 2 days, and then maintained with $1 \mu \mathrm{g} / \mathrm{mL}$ insulin and $1 \mu \mathrm{M}$ troglitazone for another 6 days. Cells were harvested at indicated days for RNA and protein extraction.

Cells were transiently transfected with equal molar amounts of luciferase-fusion PPAR $\gamma 1$ and PPAR $\gamma 2$ constructs or pGL3-basic backbone in antibiotics-free growth media using the Lipofectamine 2000 reagent according to the manufacturer's protocol (Invitrogen). pRL-tK (Promega) containing the Renilla luciferase gene was co-transfected in order to normalize transfection efficiencies. To examine the ability of MAGED1 in regulation the transcription of Pparg, pCDNA3.1-MAGED1 vector, fragments those containing the proximal promoters of Pparg1 (-1500bp) and Pparg2 (-677, $-2275 \mathrm{bp})$ incorporated into the luciferase-fusion reporter constructs, and pRL-tK were transfected. Cells were then lysed at $48 \mathrm{~h}$ after transfection, and the luciferase activities were determined using the dual-luciferase reporter assay system (Promega).

\section{Quantitative RT-PCR}

Total RNA from adipocyte tissues was extracted with RNAiso plus $(9108$, TaKaRa). Primary cDNA was synthesized by the PrimeScript RT Kit together with the gDNA Eraser kit (RR047A, TaKaRa). Quantitative RT-PCR was performed using the SYBR Premix Ex Taq (RR420A, TaKaRa) in an ABI 7700 sequence detector (Applied Biosystems). The relative abundance of target gene transcripts was normalized to levels of $36 B 4$.

\section{Protein isolation, immunoprecipitation and Western blot}

Cells were washed and lysed in denaturing lysis buffer (30 mM HEPES at pH 7.6, $100 \mathrm{mM} \mathrm{NaCl}, 0.5 \%$ Nonidet P-40, protease inhibitor cocktail from Roche, $1 \mathrm{mM}$ $\mathrm{Na}_{3} \mathrm{VO}_{4}$ and $20 \mathrm{mM} \mathrm{NaF}$ ) on ice for $10 \mathrm{~min}$ and centrifuged at $12,000 \mathrm{~g}$ for $10 \mathrm{~min}$. Tissues were collected quickly after killing mice by cervical dislocation, dipped into liquid nitrogen and homogenized immediately in complete RIPA lysis buffer $(50 \mathrm{mM}$ Tris- $\mathrm{HCl} \mathrm{pH} 7.4,1 \%$ Nonidet P-40, $0.25 \%$ Na-deoxycholate, $150 \mathrm{mM} \mathrm{NaCl}, 1 \mathrm{mM}$ EDTA and protease inhibitors) on ice-water bath. The homogenate was incubated at $4^{\circ} \mathrm{C}$ for $1 \mathrm{~h}$ with continuous rotation. Protein concentration was measured by Bradford's method (Protein assay dye reagent concentrate, Cat. No. 500-0006, Bio-Rad).

Five hundred micrograms of protein samples were incubated with $1 \mu \mathrm{g}$ of indicated antibodies and protein $\mathrm{A} / \mathrm{G}$ beads on a rotator at $4^{\circ} \mathrm{C}$ overnight. The beadantibody-antigen complexes were washed four times in PBS with protein inhibitors. The beads were finally boiled in $80 \mu \mathrm{L} 1 \times$ loading buffer and the supernatant was collected for further analyses (Cao et al. 2010, Svensson et al. 2013).

Protein samples were separated by SDS-PAGE and transferred to PVDF membranes (Millipore). Membranes were blocked with $5 \%$ fat-free milk in TBST $(0.1 \%$ Tween20 in TBS) and incubated with antibodies diluted in 5\% BSA/TBST at $4^{\circ} \mathrm{C}$ overnight. Next day, membranes were washed with TBST for $4 \times 5 \mathrm{~min}$, incubated with HRPconjugated secondary antibody diluted in 5\% fat-free milk/TBST at room temperature for at least $1 \mathrm{~h}$, washed with TBS and detected using ECL Western Blotting substrates (Cat. No. 32106, Pierce). If needed, membranes were stripped with stripping buffer (2\% SDS, $62.5 \mathrm{mM}$ Tris, $\mathrm{pH} 6.8,100 \mathrm{mM} 2$-mercaptoethanol) at $50^{\circ} \mathrm{C}$ for $30 \mathrm{~min}$.

\section{Statistical analyses}

Data were presented as the means \pm s.E.M. Statistical differences were determined by unpaired Student's $t$-test (for two groups) or one-way ANOVA with Tukey's multiple comparisons test (for three or more groups).

\section{Results}

\section{MAGED1 negatively regulates adipogenesis}

To determine the potential role of MAGED1 in adipogenesis, we first examined its expression during the differentiation of 3T3-L1 preadipocytes. We found that levels of both Maged1 mRNA and MAGED1 protein gradually decreased after the adipogenic induction (Fig. 1A and B). In the gonadal WATs (gWAT) in mice, the expression of Maged1 mRNA reduced when adipogenesis 
was induced by high-fat diet (HFD) feeding (Fig. 1C). These data indicate that MAGED1 expression is negatively associated with adipogenesis. To directly determine the effect of MAGED1 on adipogenesis, we differentiated WT and MAGED1- KO MEFs into the adipogenic lineage with IBMX, dexamethasone and insulin (collectively termed as MDI) or MDI plus triiodothyronine (T3). MAGED1deficient MEFs showed increased efficiency in adipogenesis when compared to WT MEFs (Fig. 1D). Consistent with this result, the adipogenic response of SVF cells from gWAT was more robust in KO mice than in WT mice (Fig. 1E). We found that the expression of marker genes, such as total Pparg, Pparg2 and Adipoq, was significantly upregulated in induced $\mathrm{KO}$ adipocytes, particularly at late time points (Fig. 1F, G and H). The nuclear receptor PPAR $\gamma$ is a master regulator of adipogenesis (Farmer 2006, Rosen \& MacDougald 2006), and levels of PPAR $\gamma$ protein were evidently increased in induced $\mathrm{KO}$ adipocytes, when compared to WT controls (Fig. 1I). Collectively, these data demonstrate that MAGED1 is a negative regulator of adipogenesis.

\section{MAGED1 inhibits the stability and activity of PPAR $\gamma$}

In its MAGE domain, MAGED1 contains two LXXLL motifs that are required for interactions with nuclear receptors
(Supplementary Fig. 1A, see section on supplementary data given at the end of this article). Indeed, immunoprecipitation showed that MAGED1 bound to both PPAR $\gamma 1$ and PPAR 2 (Fig. 2A). We then assayed protein stability using cycloheximide (CHX), which is an inhibitor of protein biosynthesis (Ruan et al. 2012). MAGED1 overexpression reduced the stability of both PPAR $\gamma 1$ and PPAR 2 (Fig. 2B and $\mathrm{C}$ ). In addition, using a PPAR response element (PPRE)-driven luciferase reporter, we found that MAGED1 prevented the induction of luciferase activity by PPAR $\gamma 1$ in 3T3-L1 cells (Fig. 2D) and NIH/3T3 cells (Supplementary Fig. 1B). PPAR $\gamma$ binds to its own promoter and activates its own transcription (Lefterova et al. 2008, Nielsen et al. 2008). We also observed decreased Pparg1 and Pparg2 promoter activities when MAGED1 was overexpressed in 3T3-L1 cells (Fig. 2E) and NIH/3T3 cells (Supplementary Fig. 1C, $\mathrm{D}, \mathrm{E}$ and $\mathrm{F})$. On the other hand, MAGED1 knockdown in NIH/3T3 cells increased Pparg2 promoter activities (Supplementary Fig. 1G). These data suggest that MAGED1 may inhibit adipogenesis by suppressing the stability and activity of PPAR $\gamma$.

\section{Increased adiposity in MAGED1-KO mice}

We then sought to determine whether MAGED1 regulated adipogenesis in vivo. In young male mice when there was
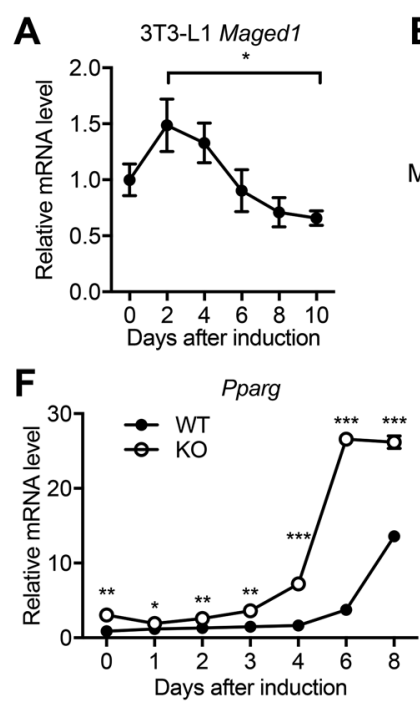

B
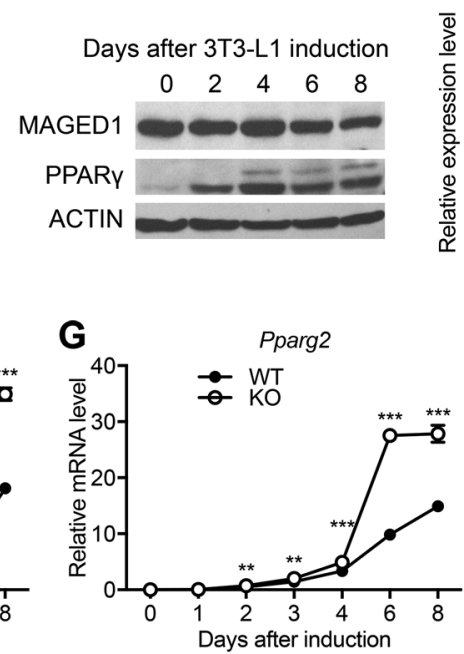

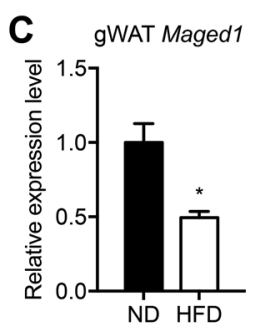

D

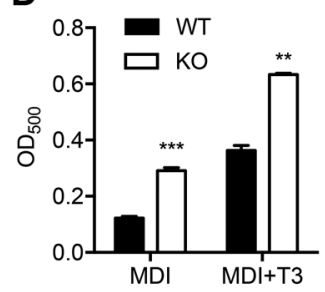

E
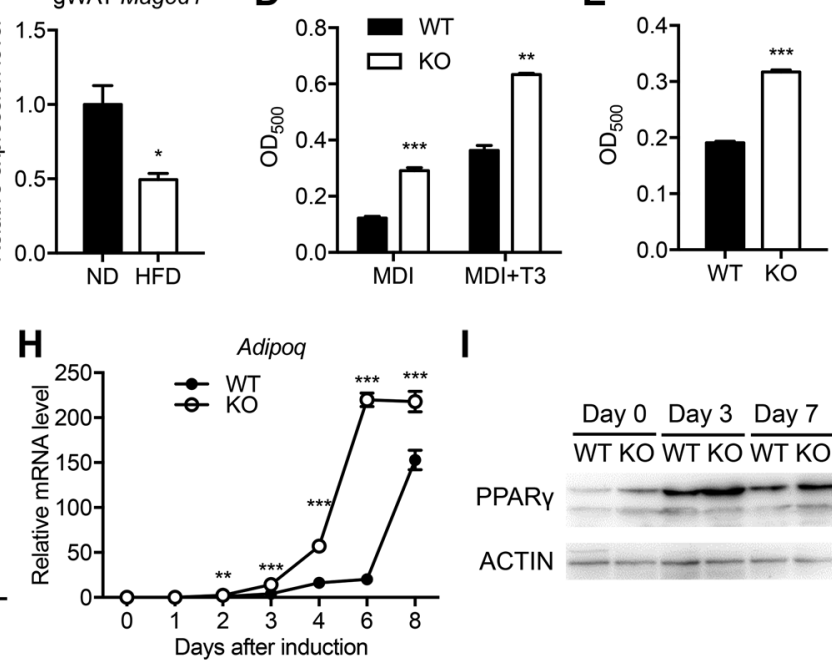

I

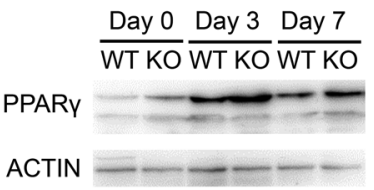

Figure 1

MAGED1 controls adipogenesis in vitro. (A) Expression levels of Maged1 during the adipogenic induction of 3T3-L1 cells ( $n=6)$. (B) Expression of MAGED1 and PPAR $\gamma$ proteins during 3T3-L1 adipocyte differentiation. (C) mRNA levels of Maged1 in gWAT from mice fed with NC or HFD ( $n=4-5$ ). (D) WT and KO MEFs were differentiated into adipocytes by MDI or MDI plus T3 and stained with Oil-Red O. The staining was quantified by spectrophotometry at OD 500 of the dye extracted from cells $(n=3)$. (E) SVF cells from gWAT of WT and KO mice were differentiated into adipocytes and Oil-Red O staining was quantified ( $n=9)$. (F, G and H) Relative mRNA levels of total Pparg, Pparg2 and Adipoq in differentiated WT and KO SVFs ( $n=6-7)$. (I) Expression of PPAR $\gamma$ protein in differentiated WT and KO SVFs. Data presented as mean \pm S.E.M. $* P<0.05, * * P<0.01$ and $* * * P<0.001$ by one-Way ANOVA with Tukey's multiple comparisons test (A) and two-tailed $t$-test $(C, D, E, F, G$ and $H)$.

$\begin{array}{lr}\text { https://joe.bioscientifica.com } & \text { C } 2018 \text { Society for Endocrinology } \\ \text { https://doi.org/10.1530/JOE-18-0349 } & \text { Published by Bioscientifica Ltd. } \\ \text { Printed in Great Britain }\end{array}$


A

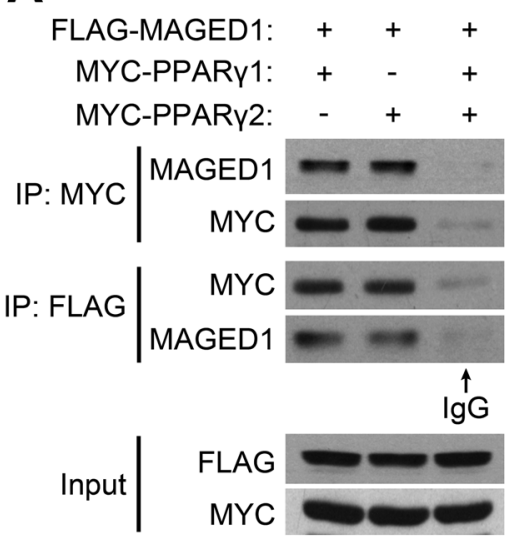

B

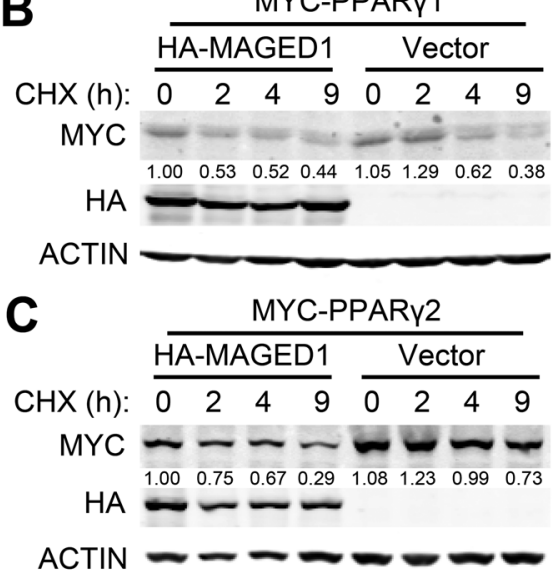

D

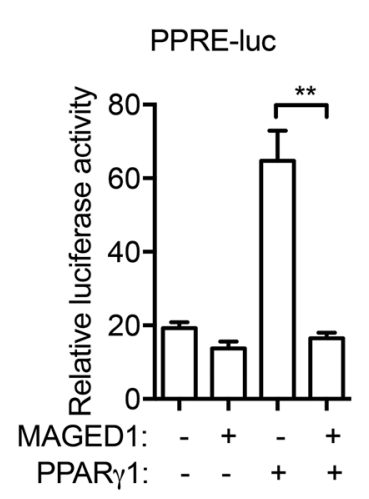

$\mathbf{E}$

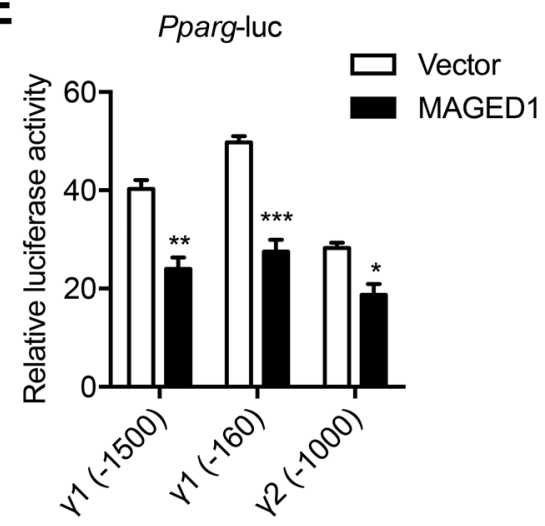

\section{Figure 2}

MAGED1 inhibits PPAR $\gamma$ stability and activity. (A) FLAG-tagged MAGED1 was co-expressed with MYC-tagged PPAR $\gamma 1$ or PPAR $\gamma 2$ in HEK 293 cells and their interactions were determined by reciprocal immunoprecipitation with anti-MYC and anti-FLAG antibodies. Normal IgG was used for immunoprecipitation in the last lane as negative controls. (B and C) PPAR $\gamma 1$ (B) and PPAR 2 (C) were co-transfected with vector or MAGED1 in HEK 293 cells and then treated with $\mathrm{CHX}$ for indicated times. Expression of PPAR $\gamma$ was determined by immunoblotting. Relative levels of PPAR $\gamma$ protein were shown below the Myc blots. (D) PPRE-luciferase assay in 3T3-L1 cells $(n=4)$. (E) Pparg1 and Pparg2 promoter-driver luciferase assay in the absence/presence of MAGED1 in 3T3-L1 cells $(n=4)$. Data presented as mean \pm S.E.M. ${ }^{*} P<0.05, * * P<0.01$, and $* * * P<0.001$ by One-way ANOVA with Tukey's multiple comparisons test (D) and two-tailed t-test (E). no difference in body weight (Fig. 3A), no difference in WAT weight was observed at 2 weeks (Fig. 3B). At 3 weeks of age, there was a trending increase in weight of gonadal and posterior subcutaneous WAT in KO mice (Fig. 3C). At 4 weeks of age, compared to WT mice, KO mice had significantly heavier gonadal, posterior subcutaneous and interscapular WAT and showed a tendency to increase in inguinal and perirenal fat weight (Fig. 3D). No change in brown adipose tissue (BAT) weight was observed (Fig. 3B, C and D), indicating that the effect of MAGED1 on adipogenesis is either specific to WAT only or not evident in BAT at this developmental stage. We then further analyzed gWAT and found no changes in adipocyte number or size at 2 weeks (Fig. 3E, F and $\mathrm{G})$. We could observe adipocyte hyperplasia starting at 3 weeks of age (Fig. 3E) and adipocyte hypertrophy not until 4 weeks of age (Fig. 3F, G and H). These data demonstrate that loss of MAGED1 in mice results in increased adiposity in early life.

Consistent with the inhibitory effect of MAGED1 on PPAR $\gamma$ in vitro, we found that PPAR $\gamma$ protein levels were substantially upregulated in gWAT in KO mice (Fig. 4A).
mRNA levels of Pparg and its target genes involved in adipogenesis, lipogenesis and glucose metabolism were all increased in KO mice (Fig. 4B). These results demonstrate that loss of MAGED1 increases PPAR $\gamma$ levels and promotes adipogenesis in vivo.

Cell proliferation is essential for adipocyte differentiation (Fajas 2003). The MTT assay showed that SVF cells from KO mice had higher proliferation rates than WT cells in vitro (Fig. 4C). Regulators of cell cycle progression, including Cyclin D1 and A2, increased their expression in KO SVF cells (Fig. 4D). To directly assess adipocyte proliferation in vivo, we performed bromodeoxyuridine (BrdU) labeling in mice from postnatal day 7 to 14 . Immunostaining in gWAT showed that significantly more BrdU-tracked adipocytes were present in $\mathrm{KO}$ mice than WT mice (Fig. 4E and F). We then performed flow cytometry of isolated SVF cells from gWAT and found KO mice had more CD29+CD34+Sca- $1^{+}$adipocyte precursors (Fig. 4G) (Rodeheffer et al. 2008, Berry \& Rodeheffer 2013), suggesting an increased adipogenic potential in MAGED1-deficient mice. 


\begin{tabular}{l|l|l|l|} 
Journal of & Q Wang, J Tang et al. & MAGED1 inhibits adipogenesis & $\mathbf{2 3 9 : 2}$ \\
Endocrinology & & $\mathbf{1 7 3}$
\end{tabular}

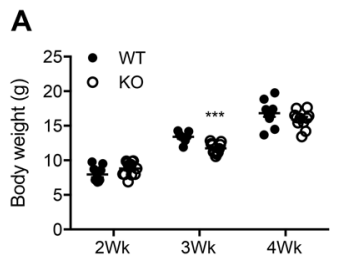

E

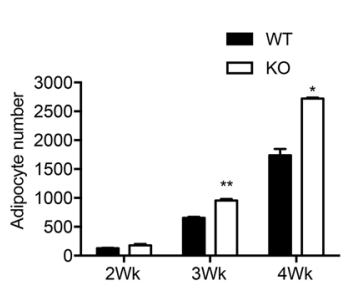

B

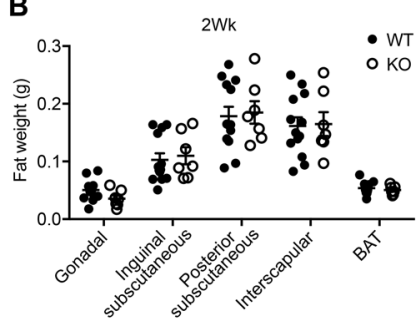

$\mathbf{F}$

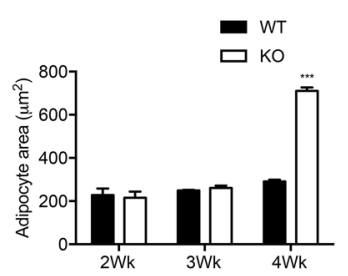

C

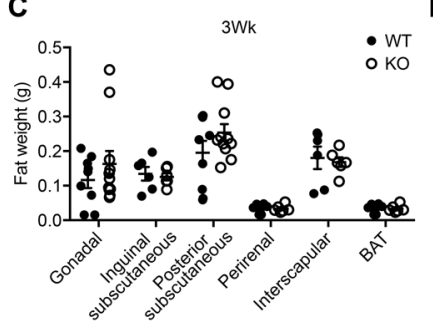

$\mathbf{G}$

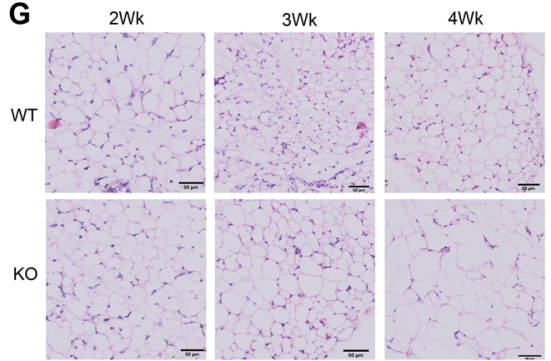

D

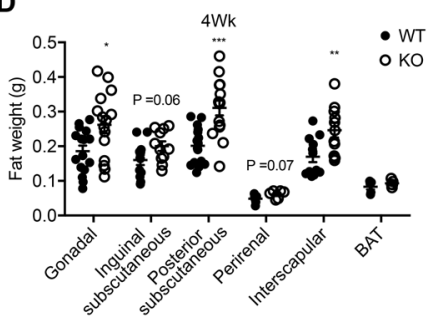

H

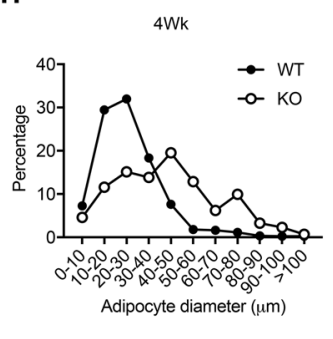

Figure 3

Increased adiposity in young MAGED1-KO mice. (A) Body weight of 2-4 weeks old WT and KO mice $(n=7-13)$. (B, C and D) Weight of different fat depots in 2-week-old ( $B, n=7-13$ ), 3-week-old ( $C, n=6-11)$ and 4-week-old ( $D, n=5-16)$ mice. (E and F) Adipocyte numbers (E) and cell sizes (F) in gWAT $(n=20)$. (G) Representative H\&E images of gWAT. (H) Frequency distribution of adipocyte sizes in gWAT $(n=20)$. Data presented as mean \pm s.E.M. or scatter dot blot with lines at mean and s.E.M. ${ }^{*} P<0.05, * * P<0.01$ and $* * * P<0.001$ by two-tailed $t$-test.

A

D

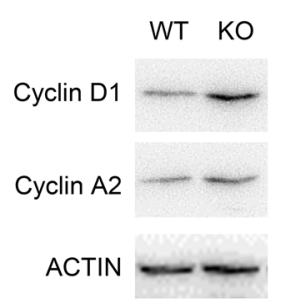

B

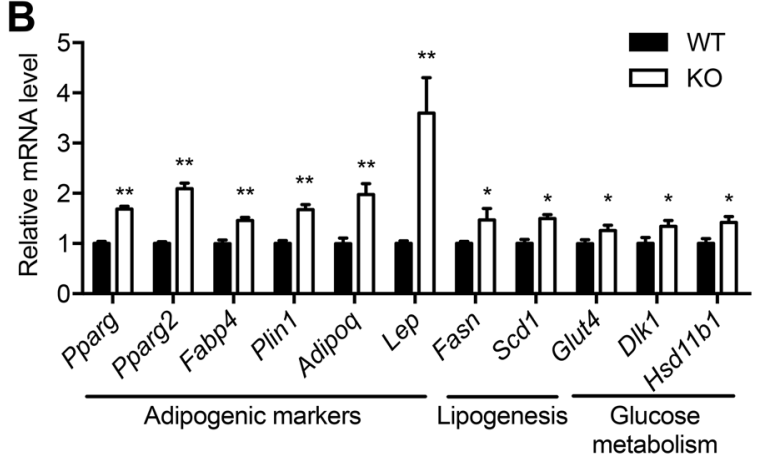

$\mathbf{F}$

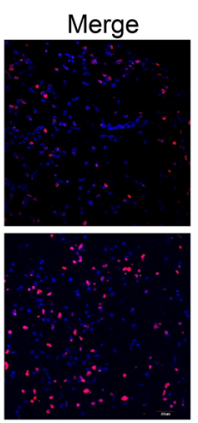

C

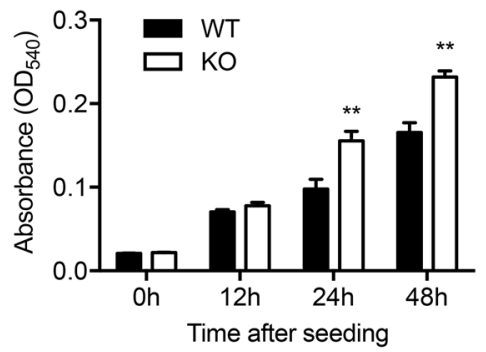

G

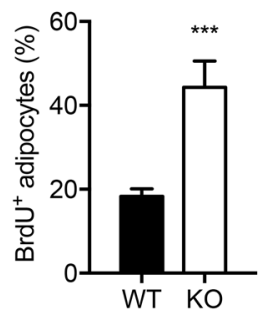

Figure 4

Enhancement of adipogenesis in MAGED1 KO mice. (A) Expression of PPAR in gWAT shown by Western blotting. (B) Quantitative RT-PCR of PPAR $\gamma$ target genes in gWAT in 4-week-old mice $(n=5)$. (C) MTT assay of cultured preadipocytes $(n=11-14)$. (D) Expression of Cyclin D1 and A2 in culture SVF cells. (E) Immunostaining of BrdU in gWAT from mice injected with BrdU from postnatal day 7 to 13. (F) Quantification of the percentage of BrdU+ adipocytes $(n=7)$. (G) Frequency of CD29+CD34+Sca-1+ adipocyte precursors in gonadal SVF cells $(n=3)$. Data presented as mean \pm s.E.M. $* P<0.05$, $* * P<0.01$ and $* * * P<0.001$ by two-tailed $t$-test. 


\section{MAGED1-KO mice develop late-onset obesity}

We then sought to determine the long-term energy homeostasis in MAGED1-KO mice. We found that KO males gained more weight than WT mice starting from around week 19 (Fig. 5A). Body composition analyses showed that there was no difference in lean mass and only fat weight and percentage were increased in $\mathrm{KO}$ mice (Fig. 5B). Consistent with findings in young mice (Fig. 3), all WAT depots were hypertrophic (Fig. 5C). Similarly, KO females also developed late-onset obesity (Fig. 5D), suggesting no sex difference in the effect of MAGED1 on body weight control. We then profiled serum levels of adipokines and lipids. Similar to increased mRNA levels of Lep and Adipoq in $\mathrm{KO}$ adipose tissue (Fig. 4), levels of serum LEPTIN (Fig. 5E and F) and ADIPONECTIN (Fig. 5G and $\mathrm{H}$ ) in $\mathrm{KO}$ mice were higher than WT mice, even before obesity was apparent. However, we did not observe any changes in serum levels of triglyceride, cholesterol or free fatty acids at all ages we examined (Fig. 5I, J and
$\mathrm{K})$, indicating that increased fat was mostly stored in adipocytes and did not induce lipotoxicity in KO mice.

To determine what caused obesity in $\mathrm{KO}$ mice, we performed metabolic cage studies. At 6 weeks of age when no difference in body weight was observed, $\mathrm{KO}$ male mice consumed less food at some time points, but total food intake was comparable between WT and KO mice (Fig. 6A). A tendency of reduced RER in KO mice was observed (Fig. 6B). Total energy expenditure indicated by calculated heat production was reduced in $\mathrm{KO}$ mice during early hours into the dark phase (Fig. 6C). Reduced physical activity was also observed in $\mathrm{KO}$ mice, particularly during the dark phase (Fig. 6D). We then repeated the metabolic cage study in 4-month-old male mice and body weightmatched mice were selected to avoid confounding factors in calculating energy metabolism (Tschop et al. 2012). We found that 4-month-old KO mice consumed less food during the dark phase (Fig. 6E). RER was consistently lower in $\mathrm{KO}$ mice during the dark phase and the early light phase (Fig. 6F), as a result of reduced food intake and/or
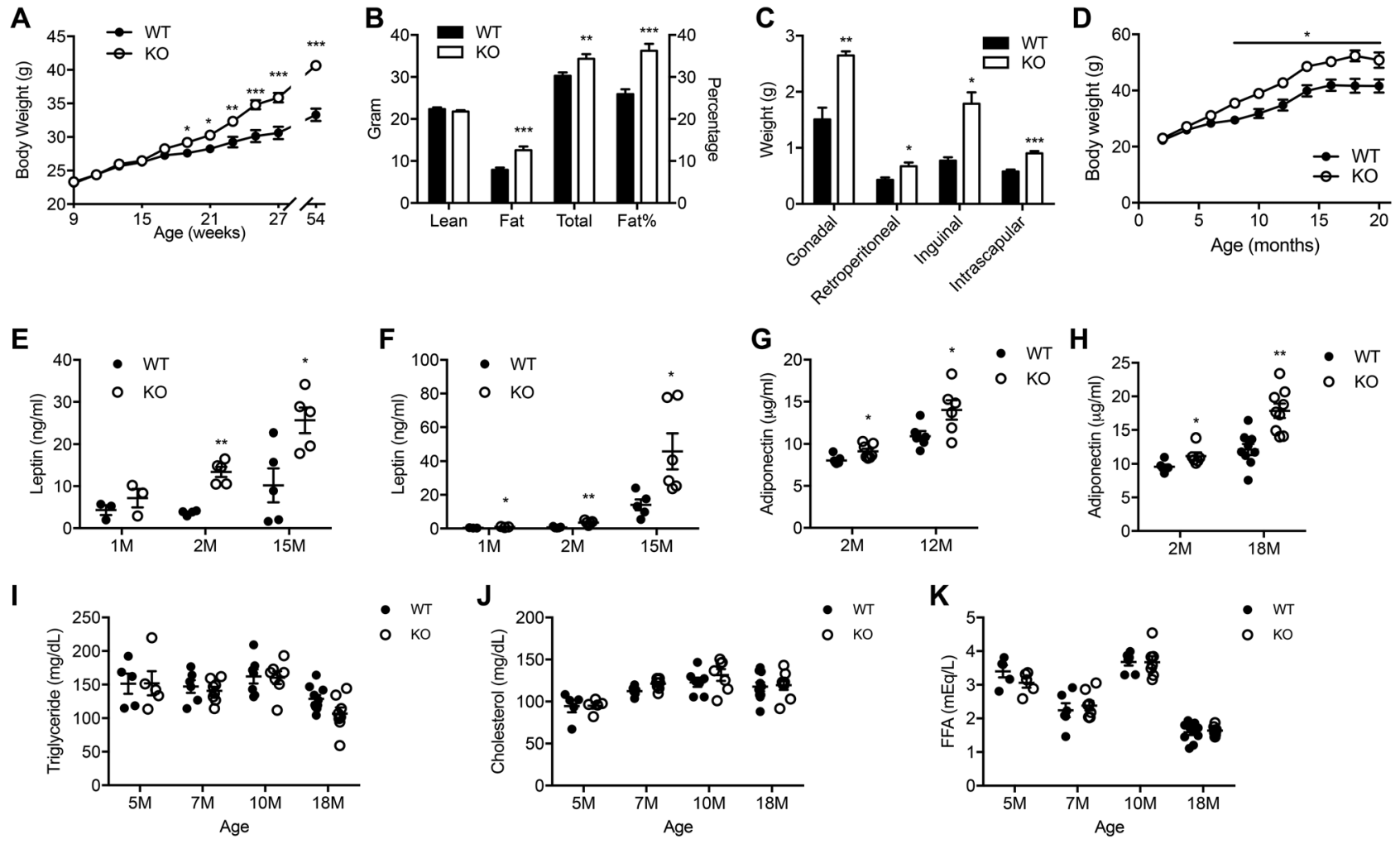

Figure 5

Late-onset obesity in MAGED1-deficient mice. (A) Growth curve of male WT and KO mice $(n=9)$. (B) Body composition of 7 months old male WT and KO mice $(n=9)$. (C) Adipose weight of 1-year-old male WT and KO mice $(n=4-5)$. (D) Growth curve of female WT and KO mice $(n=10-11)$. (E and F) Serum levels of leptin in fed (E) and fasted (F) mice $(n=3-6)$. (G and H) Serum levels of adiponectin in fed $(G, n=6-9)$ and fasted $(H, n=6-7)$ mice. $(I, J$ and $K)$ Serum levels of triglyceride (I), cholesterol $(\mathrm{J})$ and free fatty acid $(\mathrm{K})(n=5-10)$. Data presented as mean \pm S.E.M. or scatter dot blot with lines at mean and S.E.M. ${ }^{*} P<0.05, * * P<0.01$ and $* * * P<0.001$ by two-tailed $t$-test.

https://joe.bioscientifica.com https://doi.org/10.1530/JOE-18-0349
() 2018 Society for Endocrinology Published by Bioscientifica Ltd. Printed in Great Britain 

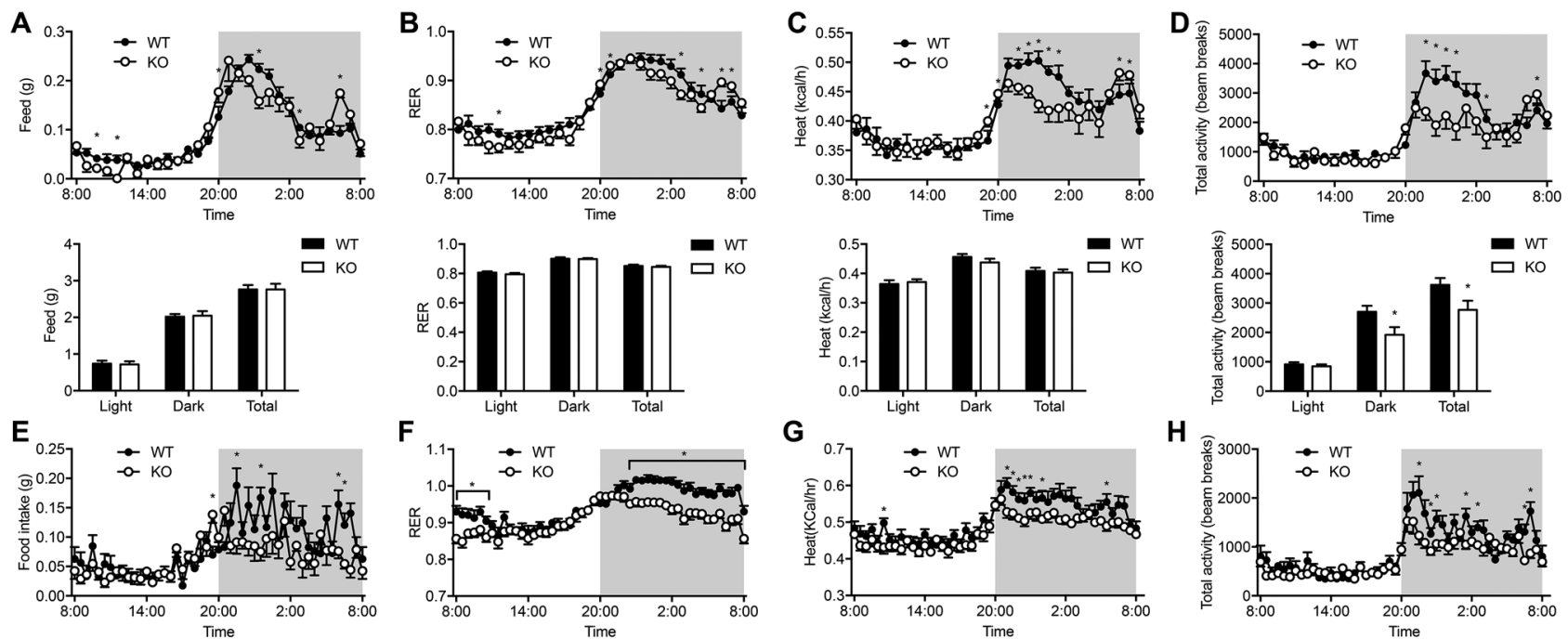

G
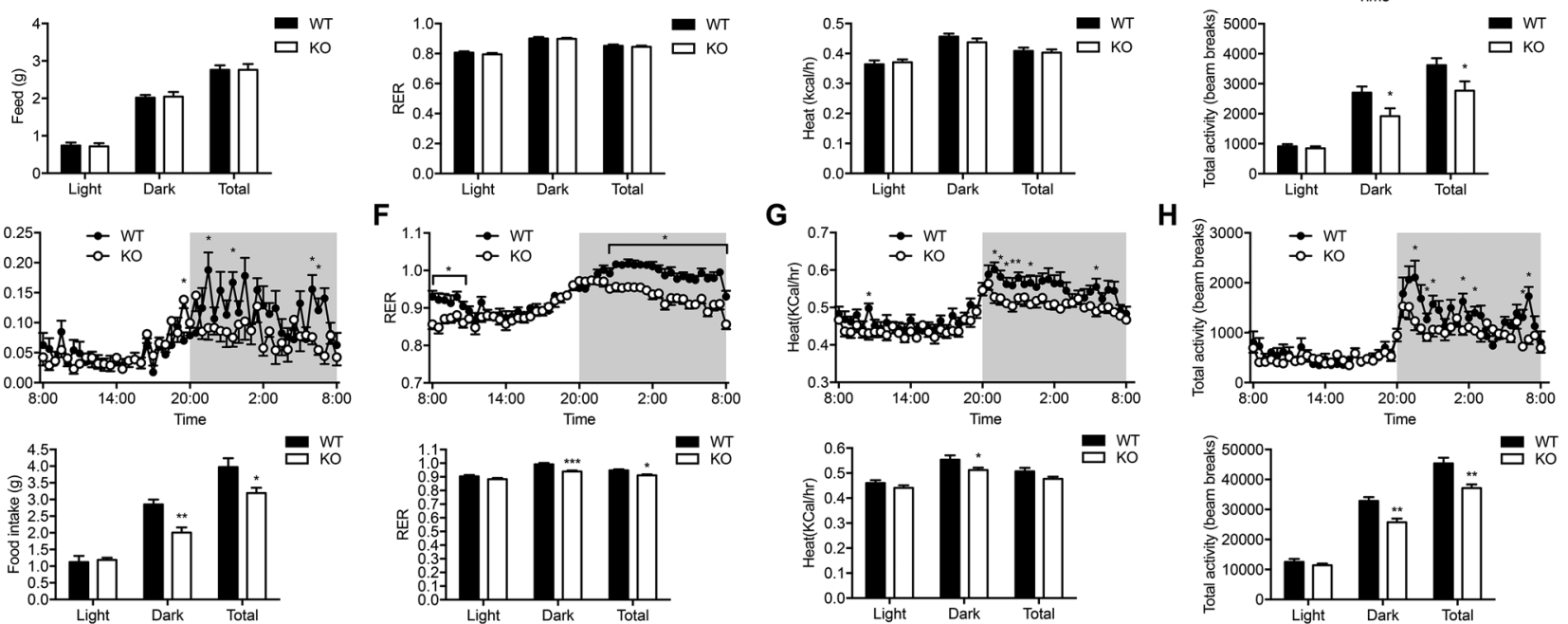

Figure 6

Energy metabolism in MAGED1 mice. (A, B, C and D) Metabolic cage studies of 6-week-old male WT and KO mice ( $n=7-9)$ showing food intake (A), RER $(B)$, heat production (C) and physical activity (D). (E, F, G and H) Metabolic cage studies of body weight-matched 4-month-old male WT and KO mice $(n=8)$ showing food intake (E), RER (F), heat production $(G)$ and physical activity $(H)$. Absolute levels during the day and night shown at the top and average levels shown at the bottom. Data presented as mean \pm s.E.M. ${ }^{*} P<0.05, * * P<0.01$ and $* * * P<0.001$ by two-tailed $t$-test.

preferred fat utilization. Heat production (Fig. 6G) and physical activity (Fig. $6 \mathrm{H}$ ) were consistently lower in $\mathrm{KO}$ mice during the dark phase. However, we did not observe any changes in the morphology (Supplementary Fig. 2A) or UCP1 expression (Supplementary Fig. 2B) in BAT in KO mice. Taken together, these data indicate that MAGED1 KO mice develop energy imbalance and late-onset obesity.

\section{Improved glucose metabolism and insulin sensitivity in MAGED1 KO mice}

Activation of PPAR $\gamma$ in adipose tissues improves glucose tolerance and insulin sensitivity in diabetic patients and animal models (Spiegelman 1998). We then assessed systemic glucose metabolism in MAGED1-KO mice. Glucose levels in KO mice were significantly lower than WT mice during glucose tolerance tests at ages of 3 months (Fig. 7A) and 6 months (Fig. 7B). ITTs demonstrated that KO mice had improved insulin sensitivity compared to WT mice before and after their body adiposity was increased (Fig. 7C and D). The reduction in fasting glucose concentrations in $\mathrm{KO}$ mice was apparent at 3 and 6 months but lost when mice were more than 1 year old (Fig. 7E and F). However, these old $\mathrm{KO}$ mice still had lower fasting insulin levels (Fig. 7G) and reduced scores of the homeostatic model assessment of insulin resistance (HOMA-IR, Fig. 7H). Similar levels of fasting serum glucagon suggested that the improved glucose metabolism was not a result of functional changes in pancreatic $\alpha$ cells (Fig. 7I). Hepatic glucose production was not affected in KO mice, shown by the pyruvate tolerance test (Supplementary Fig. 3A) and gluconeogenic gene expression (Supplementary Fig. 3B). Glucose-stimulated insulin secretion in vivo (Supplementary Fig. 3C) and in isolated pancreatic islets (Supplementary Fig. 3D) was also normal, indicating intact $\beta$ cell function in $\mathrm{KO}$ mice. These data demonstrate that obesity in MAGED1-KO mice was not associated with an impairment in glucose metabolism, possibly because enhanced adipogenesis and lipid-storing ability eliminated the deleterious effects of lipids on tissues like liver and pancreas.

Finally, we assessed insulin signaling directly. Treating MEFs with increasing concentrations of insulin for $5 \mathrm{~min}$ (Fig. $8 \mathrm{~A}$ ) or $100 \mathrm{nM}$ insulin for various time points (Fig. 8B) showed that AKT phosphorylation and total IRS1 levels were upregulated while phosphorylated JNK was decreased in $\mathrm{KO}$ cells, indicating that loss of MAGED1 sensitizes insulin signaling. Consistently, 
A

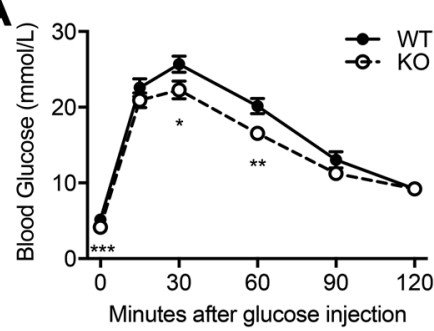

C

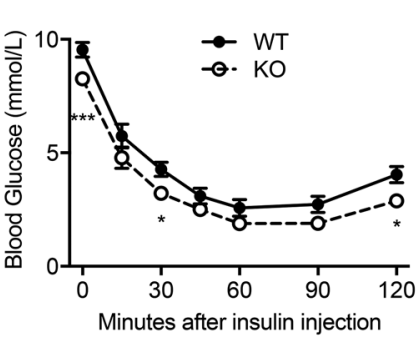

$E$

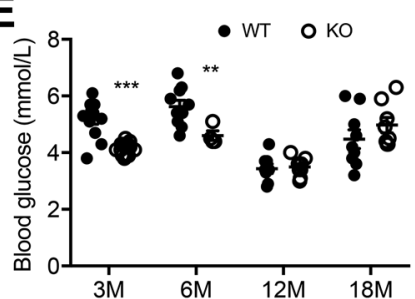

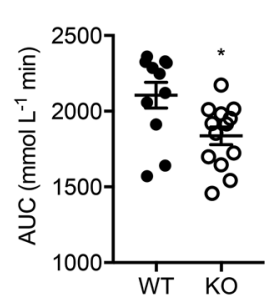

B
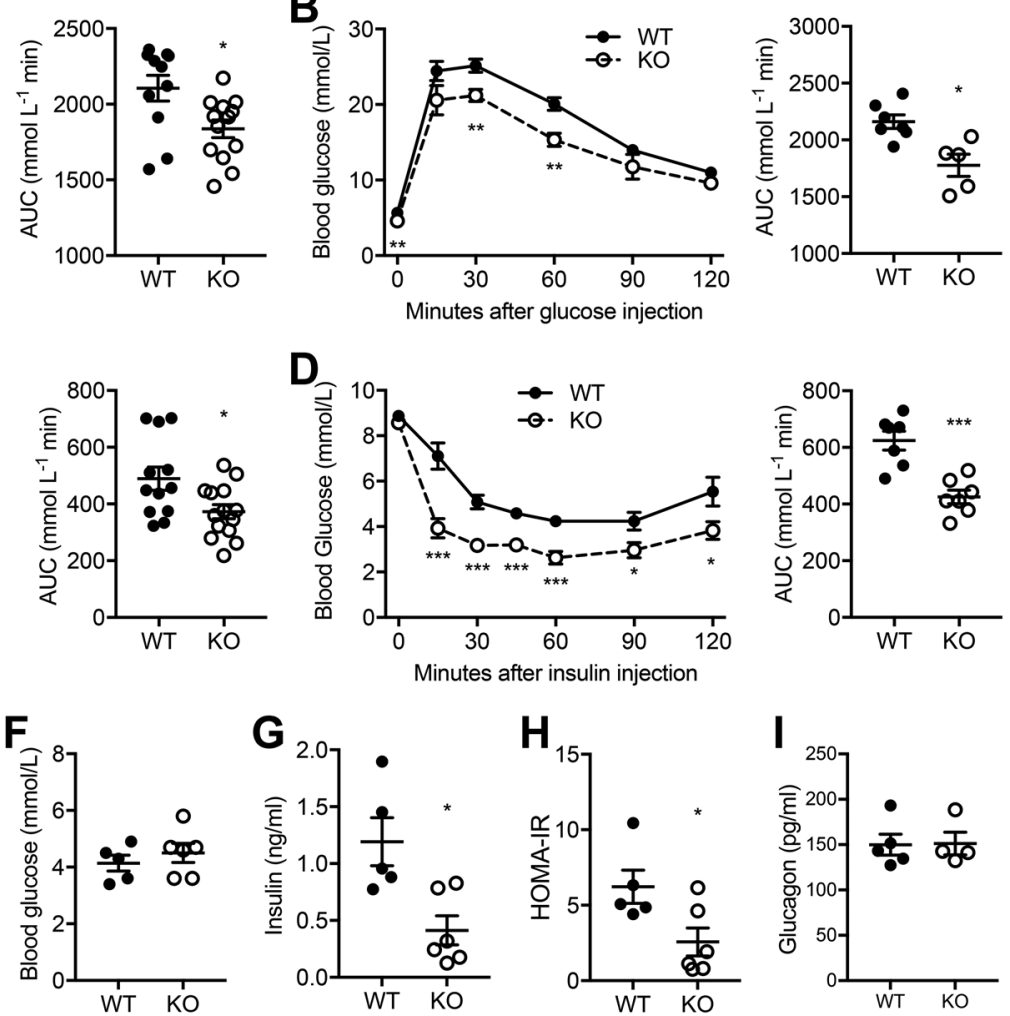

Figure 7

Glucose metabolism in MAGED1 mice. (A and B) Glucose tolerance tests with a dose of $2 \mathrm{~g} / \mathrm{kg}$ BW glucose in 3 months (A, $n=11-13$ ) and 6 -month-old $(B, n=5-7)$ mice. Area under curves shown to the right. ( $C$ and $D)$ Insulin tolerance tests with a dose of $0.75 \mathrm{U} / \mathrm{kg} \mathrm{BW}$ insulin in $3-\mathrm{month}(\mathrm{C}, n=12-14)$ and 6-month ( $D, n=7$ )-old mice. Area under curves shown to the right. (E) Blood glucose levels of overnight-fasted mice at different ages ( $n=4-13)$. $(F, G, H$ and I) 15.5 months old mice were fasted overnight and levels of blood glucose (F), serum insulin (G), HOMA-IR (H) and serum glucagon (I) were determined $(n=4-5)$. Data presented as mean \pm S. E.M. or scatter dot blot with lines at mean and S.E.M. ${ }^{*} P<0.05, * * P<0.01$ and $* \star * P<0.001$ by two-tailed $t$-test.

phosphorylation of AKT at S473 was increased in gWAT of KO mice, compared to WT controls (Fig. 8C). Levels of JNK phosphorylation, however, were comparable between genotypes (Fig. 8C). Obesity generally is associated with a state of chronic, low-grade inflammation (Xu et al. 2003). However, the expression of inflammatory genes including Il6 and Tnfa was not changed in gWAT in KO mice (Fig. 8D). Similarly, serum levels of TNF $\alpha$ were not elevated in $\mathrm{KO}$ mice at all ages examined (Fig. 8E). Taken together, our data demonstrate that loss of MAGED1 in mice enhances insulin sensitivity and improves glucose metabolism.

\section{Discussion}

MAGE family consists of more than 50 genes, most of which are localized in clusters in the $\mathrm{X}$ chromosome (Chomez et al. 2001, Lee \& Potts 2017). They can be broadly categorized into the cancer-testis antigen type I that includes MAGE- $\mathrm{A},-\mathrm{B}$ and $-\mathrm{C}$, and the ubiquitous type II that includes MAGE-D, -E, -F, -G, -H, -L and NECDIN. While type I MAGEs control germ cell development and function as oncogenes to drive tumorigenesis, type II MAGEs are important for neurodevelopment (Lee \& Potts 2017). MAGEL2 and NECDIN are two of the five genes inactivated in Prader-Willi syndrome (PWS), a genetic condition that causes hyperphagia and severe obesity in affected children. Mice lacking the Magel2 gene phenocopy human PWS, being overweight with increased adiposity (Bischof et al. 2007, Mercer et al. 2013). Disruption of the Necdin gene in mice also results in hypothalamic and behavioral defects reminiscent of human PWS (Muscatelli et al. 2000). NECDIN is highly expressed in preadipocytes and loss of NECDIN promotes adipogenesis in vitro and adipose hyperplasia in vivo (Bush \& Wevrick 2012, Fujiwara et al. 2012). Here, we showed that MAGED1 is another MAGE family member that negatively regulates https://joe.bioscientifica.com https://doi.org/10.1530/JOE-18-0349
(C) 2018 Society for Endocrinology Published by Bioscientifica Ltd. Printed in Great Britain 
A

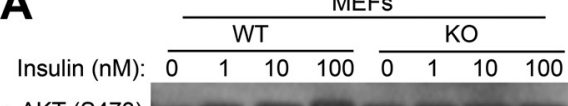

p-AKT (S473)

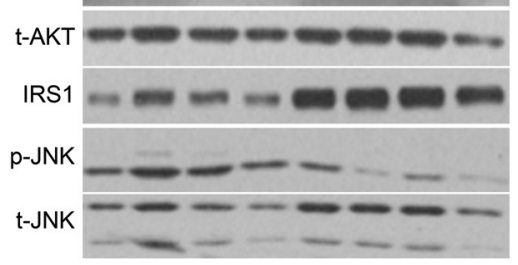

C

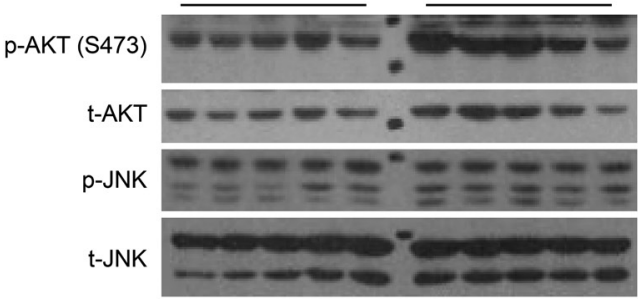

D

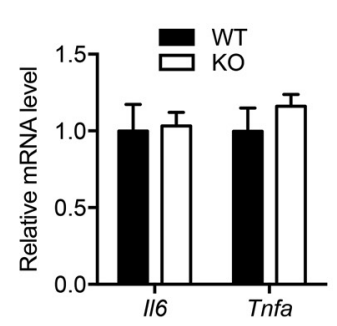

B
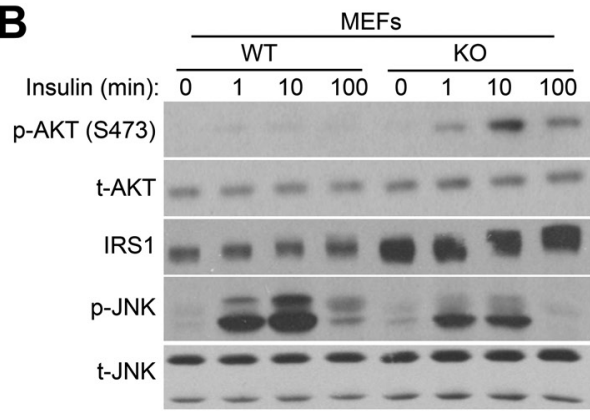

E

Figure 8

MAGED1 controls insulin sensitivity. (A and B) Immortalized WT and KO MEFs were treated with various concentrations of insulin for $5 \mathrm{~min}$ (A) or $100 \mathrm{nM}$ insulin for various times (B). Total proteins were run for immunoblotting with indicated antibodies. (C) gWAT proteins from ad libitum-fed 8-month-old WT and KO mice were subjected to immunoblotting $(n=5)$. (D) Expression of $I / 6$ and Tnfa genes in gWAT $(n=5)$. (E) Serum levels of TNF $\alpha$ in WT and KO mice at different ages $(n=3-8)$. Data presented as mean \pm S.E.M. or scatter dot blot with lines at mean and S.E.M.

adipogenesis and MAGED1 deficiency leads to adipose hyperplasia and obesity in mice. It will be interesting to determine in the future whether other type II MAGEs also modulate adipogenesis and systemic metabolism and whether a unified mechanism can be adopted.

Besides promoting adipogenesis, MAGED1-KO mice also show reduced food intake and physical activity when compared to WT littermates, suggesting possible functional defects in the hypothalamus. In supporting its neuronal function, MAGED1 was previously shown to regulate neuronal differentiation and survival (Salehi et al. 2000), modulate circadian rhythm (Wang et al. 2010) and be involved in depression (Mouri et al. 2012), learning and memory formation (Yang et al. 2015), and social interactions and sexual behavior (Dombret et al. 2012). Of note, Dombret et al. also observed that MAGED1-KO mice develop very-late-onset obesity (when 1 year old) that is associated with hyperphagia and reduced motor activity (Dombret et al. 2012). However, obesity could be seen in our MAGED1-KO mice much earlier in both sexes (Fig. 5) and increased adipogenesis could be observed as early as 1 month old. In addition, food intake is reduced in our MAGED1-KO mice (Fig. 6). These discrepancies between the two studies could be a result of different knockout strategies used. Dombret et al. deleted exons
4-12 of the Maged1 gene and a truncated MAGED1 fragment translated from the remaining exons 2-3 could be detected. We replaced exons 3 through 8 with the PGK-Neo cassette, and we could not detect any Maged1 mRNA or residual MAGED1 protein (data not shown). Nevertheless, future investigations using tissue-specific Maged1 deletions would help delineate the potential role of MAGED1 in hypothalamic control of metabolism.

Elegant biochemical and biophysical studies by the Potts group discovered that MAGE proteins bind to and activate the E3 RING ubiquitin ligases (Doyle et al. 2010, Hao et al. 2013, Lee \& Potts 2017). They found that MAGED1 forms a strong complex with PRAJA-1 and a weak complex with TRIM28 (Doyle et al. 2010). A previous study using yeast two-hybrid screening also identified PRAJA-1 as a MAGED1-interacting protein (Sasaki et al. 2002). The E3 ligase activity of PRAJA- 1 causes a decrease in MAGED1 protein level, thus controlling the transcription function of the homeodomain protein DLX5. Here, we demonstrated that MAGED1 interacts with both PPAR $\gamma 1$ and PPAR $\gamma 2$. Overexpression of MAGED1 reduces the stability and transcriptional activity of PPAR $\gamma 1$ and PPAR $\gamma 2$. Various E3 ligases have been reported to control PPAR $\gamma$ protein levels, including NEDD4 (Li et al. 2016) and RING proteins including ARIH2, c-CBL, LRSAM-1, RNF4, SIAH2, 
MKRN1 and TRIM23 (Kilroy et al. 2012, Kim et al. 2014, Watanabe et al. 2015). Future experiments are warranted to determine whether and which RING proteins mediate the interaction and ubiquitination of PPAR $\gamma$ proteins by MAGED1.

In MEF cells where PPAR $\gamma$ is not expressed, we found that MAGED1 KO increased IRS1 expression and insulin signaling activity (Fig. 8). IRS1, a critical mediator of the insulin pathway, has been extensively shown to be regulated by ubiquitination-dependent degradation (Xu et al. 2008, Song et al. 2013, Yang et al. 2016). We suspect that MAGED1 may function as an adaptor protein for E3 ligases to target IRS1 for degradation. Therefore, in MAGED1-KO mice, increased IRS1 expression and insulin signaling can also function upstream to activate PPAR $\gamma$ and promote adipogenesis.

Taken together, MAGED1 negatively regulates PPAR $\gamma$ stability and activity, adipogenesis and insulin sensitivity. Harnessing MAGED1 may represent a novel approach for the treatment of obesity, diabetes and related metabolic diseases.

\section{Supplementary data}

This is linked to the online version of the paper at https://doi.org/10.1530/ JOE-18-0349.

\section{Declaration of interest}

The authors declare that there is no conflict of interest that could be perceived as prejudicing the impartiality of the research reported.

\section{Funding}

This work was supported by National Natural and Science Foundation of China (31500944) to $\mathrm{Z} \mathrm{H}$; Ministry of Science and Technology of China (2014BAI02B01 and 2015BAI08B02) and National Natural Science Foundation of China (31772550) to X G; and American Heart Association (14SDG20120052), American Diabetes Association (18-IBS-167) and National Natural and Science Foundation of China (81770543) to H-B R.

\section{Author contribution statement}

Q W and J T performed most of the experiments and data analyses with the help from S J, Z H, A S and S H. Q W wrote the manuscript, together with J T. X G supervised the project and contributed to manuscript editing. H B R conceived the project, performed experiments, analyzed data and wrote the manuscript.

\section{Acknowledgments}

The authors thank Xiaoyong Yang (Yale University) for providing pGL3-Pparg1(-1500 bp)-luc, pGL3-Pparg1(-160bp)-luc and pGL3Pparg2(-1000 bp)-luc plasmids.

\section{References}

Berry R \& Rodeheffer MS 2013 Characterization of the adipocyte cellular lineage in vivo. Nature Cell Biology 15 302-308. (https://doi. org/10.1038/ncb2696)

Bischof JM, Stewart CL \& Wevrick R 2007 Inactivation of the mouse Magel2 gene results in growth abnormalities similar to Prader-Willi syndrome. Human Molecular Genetics 16 2713-2719. (https://doi. org/10.1093/hmg/ddm225)

Bush JR \& Wevrick R 2012 Loss of the Prader-Willi obesity syndrome protein necdin promotes adipogenesis. Gene $\mathbf{4 9 7} 45-51$. (https://doi. org/10.1016/j.gene.2012.01.027)

Cao CM, Zhang Y, Weisleder N, Ferrante C, Wang X, Lv F, Zhang Y, Song R, Hwang M, Jin L, et al. 2010 MG53 constitutes a primary determinant of cardiac ischemic preconditioning. Circulation 121 2565-2574. (https://doi.org/10.1161/CIRCULATIONAHA.110.954628)

Chomez P, De Backer O, Bertrand M, De Plaen E, Boon T \& Lucas S 2001 An overview of the MAGE gene family with the identification of all human members of the family. Cancer Research 61 5544-5551.

Di Certo MG, Corbi N, Bruno T, Iezzi S, De Nicola F, Desantis A, Ciotti MT, Mattei E, Floridi A, Fanciulli M, et al. 2007 NRAGE associates with the anti-apoptotic factor Che-1 and regulates its degradation to induce cell death. Journal of Cell Science $\mathbf{1 2 0}$ 1852-1858. (https://doi.org/10.1242/jcs.03454)

Dombret C, Nguyen T, Schakman O, Michaud JL, Hardin-Pouzet H, Bertrand MJ \& De Backer O 2012 Loss of Maged1 results in obesity, deficits of social interactions, impaired sexual behavior and severe alteration of mature oxytocin production in the hypothalamus. Human Molecular Genetics 21 4703-4717. (https://doi.org/10.1093/ $\mathrm{hmg} / \mathrm{dds} 310$ )

Doyle JM, Gao J, Wang J, Yang M \& Potts PR 2010 MAGE-RING protein complexes comprise a family of E3 ubiquitin ligases. Molecular Cell 39 963-974. (https://doi.org/10.1016/j.molcel.2010.08.029)

Fajas L 2003 Adipogenesis: a cross-talk between cell proliferation and cell differentiation. Annals of Medicine 35 79-85. (https://doi. org/10.1080/07853890310009999)

Farmer SR 2006 Transcriptional control of adipocyte formation. Cell Metabolism 4 263-273. (https://doi.org/10.1016/j.cmet.2006.07.001)

Floyd ZE \& Stephens JM 2002 Interferon-gamma-mediated activation and ubiquitin-proteasome-dependent degradation of PPARgamma in adipocytes. Journal of Biological Chemistry 277 4062-4068. (https:// doi.org/10.1074/jbc.M108473200)

Fujiwara K, Hasegawa K, Ohkumo T, Miyoshi H, Tseng YH \& Yoshikawa K 2012 Necdin controls proliferation of white adipocyte progenitor cells. PLoS ONE 7 e30948. (https://doi.org/10.1371/journal. pone.0030948)

Gesta S, Tseng YH \& Kahn CR 2007 Developmental origin of fat: tracking obesity to its source. Cell 131 242-256. (https://doi.org/10.1016/j. cell.2007.10.004)

Hao YH, Doyle JM, Ramanathan S, Gomez TS, Jia D, Xu M, Chen ZJ, Billadeau DD, Rosen MK \& Potts PR 2013 Regulation of WASHdependent actin polymerization and protein trafficking by ubiquitination. Cell 152 1051-1064. (https://doi.org/10.1016/j. cell.2013.01.051)

Jordan BW, Dinev D, LeMellay V, Troppmair J, Gotz R, Wixler L, Sendtner M, Ludwig S \& Rapp UR 2001 Neurotrophin receptorinteracting mage homologue is an inducible inhibitor of apoptosis protein-interacting protein that augments cell death. Journal of Biological Chemistry 276 39985-39989. (https://doi.org/10.1074/jbc. C100171200)

Kilroy G, Kirk-Ballard H, Carter LE \& Floyd ZE 2012 The ubiquitin ligase Siah2 regulates PPARgamma activity in adipocytes. Endocrinology 153 1206-1218. (https://doi.org/10.1210/en.2011-1725)

Kim JH, Park KW, Lee EW, Jang WS, Seo J, Shin S, Hwang KA \& Song J 2014 Suppression of PPARgamma through MKRN1-mediated ubiquitination and degradation prevents adipocyte differentiation. 
Cell Death and Differentiation 21 594-603. (https://doi.org/10.1038/ cdd.2013.181)

Lee AK \& Potts PR 2017 A comprehensive guide to the MAGE family of ubiquitin ligases. Journal of Molecular Biology 429 1114-1142. (https:// doi.org/10.1016/j.jmb.2017.03.005)

Lefterova MI, Zhang Y, Steger DJ, Schupp M, Schug J, Cristancho A, Feng D, Zhuo D, Stoeckert CJ Jr, Liu XS, et al. 2008 PPARgamma and C/EBP factors orchestrate adipocyte biology via adjacent binding on a genome-wide scale. Genes and Development 22 2941-2952. (https:// doi.org/10.1101/gad.1709008)

Li JJ, Wang R, Lama R, Wang X, Floyd ZE, Park EA \& Liao FF 2016 Ubiquitin ligase NEDD4 regulates PPARgamma stability and adipocyte differentiation in 3T3-L1 cells. Scientific Reports 6 38550. (https://doi. org/10.1038/srep38550)

Liu M, Xu L, Ma X, Xu J, Wang J, Xian M, Zhou X, Wang M, Wang F, Qin A, et al. 2015 MAGED1 is a negative regulator of bone remodeling in mice. American Journal of Pathology 185 2653-2667. (https://doi. org/10.1016/j.ajpath.2015.06.017)

Masuda Y, Sasaki A, Shibuya H, Ueno N, Ikeda K \& Watanabe K 2001 Dlxin-1, a novel protein that binds Dlx5 and regulates its transcriptional function. Journal of Biological Chemistry 276 5331-5338. (https://doi.org/10.1074/jbc.M008590200)

Matsuda T, Suzuki H, Oishi I, Kani S, Kuroda Y, Komori T, Sasaki A, Watanabe K \& Minami Y 2003 The receptor tyrosine kinase Ror2 associates with the melanoma-associated antigen (MAGE) family protein Dlxin-1 and regulates its intracellular distribution. Journal of Biological Chemistry 278 29057-29064. (https://doi.org/10.1074/jbc.M302199200)

Mercer RE, Michaelson SD, Chee MJ, Atallah TA, Wevrick R \& Colmers WF 2013 Magel2 is required for leptin-mediated depolarization of POMC neurons in the hypothalamic arcuate nucleus in mice. PLoS Genetics 9 e1003207. (https://doi.org/10.1371/ journal.pgen.1003207)

Mouri A, Sasaki A, Watanabe K, Sogawa C, Kitayama S, Mamiya T, Miyamoto Y, Yamada K, Noda Y \& Nabeshima T 2012 MAGE-D1 regulates expression of depression-like behavior through serotonin transporter ubiquitylation. Journal of Neuroscience 32 4562-4580. (https://doi.org/10.1523/JNEUROSCI.6458-11.2012)

Muscatelli F, Abrous DN, Massacrier A, Boccaccio I, Le Moal M, Cau P \& Cremer H 2000 Disruption of the mouse necdin gene results in hypothalamic and behavioral alterations reminiscent of the human Prader-Willi syndrome. Human Molecular Genetics 9 3101-3110. (https://doi.org/10.1093/hmg/9.20.3101)

Ng M, Fleming T, Robinson M, Thomson B, Graetz N, Margono C, Mullany EC, Biryukov S, Abbafati C, Abera SF, et al. 2014 Global, regional, and national prevalence of overweight and obesity in children and adults during 1980-2013: a systematic analysis for the Global Burden of Disease Study 2013. Lancet 384 766-781. (https:// doi.org/10.1016/S0140-6736(14)60460-8)

Nielsen R, Pedersen TA, Hagenbeek D, Moulos P, Siersbaek R, Megens E, Denissov S, Borgesen M, Francoijs KJ, Mandrup S, et al. 2008 Genome-wide profiling of PPARgamma:RXR and RNA polymerase II occupancy reveals temporal activation of distinct metabolic pathways and changes in RXR dimer composition during adipogenesis. Genes and Development 22 2953-2967. (https://doi. org/10.1101/gad.501108)

Ogden CL, Carroll MD, Kit BK \& Flegal KM 2014 Prevalence of childhood and adult obesity in the United States, 2011-2012. JAMA 311 806-814. (https://doi.org/10.1001/jama.2014.732)

Ouchi N, Parker JL, Lugus JJ \& Walsh K 2011 Adipokines in inflammation and metabolic disease. Nature Reviews Immunology 11 85-97. (https:// doi.org/10.1038/nri2921)

Rodeheffer MS, Birsoy K \& Friedman JM 2008 Identification of white adipocyte progenitor cells in vivo. Cell 135 240-249. (https://doi. org/10.1016/j.cell.2008.09.036)
Rosen ED \& MacDougald OA 2006 Adipocyte differentiation from the inside out. Nature Reviews: Molecular Cell Biology 7 885-896. (https:// doi.org/10.1038/nrm2066)

Ruan HB, Han X, Li MD, Singh JP, Qian K, Azarhoush S, Zhao L, Bennett AM, Samuel VT, Wu J, et al. 2012 O-GlcNAc transferase/ host cell factor $\mathrm{C} 1$ complex regulates gluconeogenesis by modulating PGC-1alpha stability. Cell Metabolism 16 226-237. (https://doi. org/10.1016/j.cmet.2012.07.006)

Salehi AH, Roux PP, Kubu CJ, Zeindler C, Bhakar A, Tannis LL, Verdi JM \& Barker PA 2000 NRAGE, a novel MAGE protein, interacts with the p75 neurotrophin receptor and facilitates nerve growth factordependent apoptosis. Neuron 27 279-288. (https://doi.org/10.1016/ S0896-6273(00)00036-2)

Sasaki A, Masuda Y, Iwai K, Ikeda K \& Watanabe K 2002 A RING finger protein Praja1 regulates Dlx5-dependent transcription through its ubiquitin ligase activity for the Dlx/Msx-interacting MAGE/necdin family protein, Dlxin-1. Journal of Biological Chemistry 277 22541-22546. (https://doi.org/10.1074/jbc. M109728200)

Song R, Peng W, Zhang Y, Lv F, Wu HK, Guo J, Cao Y, Pi Y, Zhang X, Jin L, et al. 2013 Central role of E3 ubiquitin ligase MG53 in insulin resistance and metabolic disorders. Nature 494 375-379. (https://doi. org/10.1038/nature11834)

Spiegelman BM 1998 PPAR-gamma: adipogenic regulator and thiazolidinedione receptor. Diabetes $\mathbf{4 7}$ 507-514. (https://doi. org/10.2337/diabetes.47.4.507)

Svensson KJ, Christianson HC, Wittrup A, Bourseau-Guilmain E, Lindqvist E, Svensson LM, Morgelin M \& Belting M 2013 Exosome uptake depends on ERK1/2-heat shock protein 27 signaling and lipid Raft-mediated endocytosis negatively regulated by caveolin-1. Journal of Biological Chemistry 288 17713-17724. (https://doi.org/10.1074/jbc. M112.445403)

Tran TT \& Kahn CR 2010 Transplantation of adipose tissue and stem cells: role in metabolism and disease. Nature Reviews Endocrinology 6 195-213. (https://doi.org/10.1038/nrendo.2010.20)

Tschop MH, Speakman JR, Arch JR, Auwerx J, Bruning JC, Chan L, Eckel RH, Farese RV Jr, Galgani JE, Hambly C, et al. 2012 A guide to analysis of mouse energy metabolism. Nature Methods 9 57-63. (https://doi.org/10.1038/nmeth.1806)

van Beekum O, Fleskens V \& Kalkhoven E 2009 Posttranslational modifications of PPAR-gamma: fine-tuning the metabolic master regulator. Obesity 17 213-219. (https://doi.org/10.1038/ oby.2008.473)

Wang X, Tang J, Xing L, Shi G, Ruan H, Gu X, Liu Z, Wu X, Gao X \& Xu Y 2010 Interaction of MAGED1 with nuclear receptors affects circadian clock function. EMBO Journal 29 1389-1400. (https://doi. org/10.1038/emboj.2010.34)

Watanabe M, Takahashi H, Saeki Y, Ozaki T, Itoh S, Suzuki M, Mizushima W, Tanaka K \& Hatakeyama S 2015 The E3 ubiquitin ligase TRIM23 regulates adipocyte differentiation via stabilization of the adipogenic activator PPARgamma. Elife $\mathbf{4}$ e05615. (https://doi. org/10.7554/eLife.05615)

Williams ME, Strickland P, Watanabe K \& Hinck L 2003 UNC5H1 induces apoptosis via its juxtamembrane region through an interaction with NRAGE. Journal of Biological Chemistry 278 17483-17490. (https://doi. org/10.1074/jbc.M300415200)

Xu H, Barnes GT, Yang Q, Tan G, Yang D, Chou CJ, Sole J, Nichols A, Ross JS, Tartaglia LA, et al. 2003 Chronic inflammation in fat plays a crucial role in the development of obesity-related insulin resistance. Journal of Clinical Investigation 112 1821-1830. (https://doi. org/10.1172/JCI19451)

Xu X, Sarikas A, Dias-Santagata DC, Dolios G, Lafontant PJ, Tsai SC, Zhu W, Nakajima H, Nakajima HO, Field LJ, et al. 2008 The CUL7 E3 ubiquitin ligase targets insulin receptor substrate 1 for ubiquitin- https://joe.bioscientifica.com https://doi.org/10.1530/JOE-18-0349 (c) 2018 Society for Endocrinology Published by Bioscientifica Ltd. Printed in Great Britain 
dependent degradation. Molecular Cell 30 403-414. (https://doi. org/10.1016/j.molcel.2008.03.009)

Yang J, Lai B, Xu A, Liu Y, Li X, Zhao Y, Li W, Ji M, Hu G, Gao X, et al. 2015 Maged1 co-interacting with CREB through a hexapeptide repeat domain regulates learning and memory in mice. Molecular Neurobiology 51 8-18. (https://doi.org/10.1007/ s12035-014-8677-x)

Yang XD, Xiang DX \& Yang YY 2016 Role of E3 ubiquitin ligases in insulin resistance. Diabetes, Obesity and Metabolism 18 747-754. (https://doi.org/10.1111/dom.12677)

Received in final form 19 July 2018

Accepted 14 August 2018

Accepted Preprint published online 18 August 2018 https://joe.bioscientifica.com

https://doi.org/10.1530/JOE-18-0349 (c) 2018 Society for Endocrinology Published by Bioscientifica Ltd. Printed in Great Britain 